International Journal of Agriculture, Environment and Bioresearch

Vol. 4, No. 05; 2019

ISSN: $2456-8643$

\title{
EVALUATION OF FISH OIL REPLACEMENT WITH JATROPHA CURCAS OIL IN DIETS FOR JUVENILE NILE TILAPIA
}

\author{
Ana C. Puello-Cruz ${ }^{a}$, Amairani Duarte-Corona ${ }^{a}$, Miguel A. Angulo-Escalante ${ }^{b}$ and Pablo Almazán-Rueda ${ }^{a}$ \\ ${ }^{a}$ Food and Development Research Center A.C., Unit in Aquaculture and Environmental Management in Mazatlan, \\ Avenida Sábalo Cerritos s / n, Mazatlan, 82100, Sinaloa, Mexico. \\ ${ }^{\mathrm{b}}$ Food and Development Research Center A.C., Agricultural Products Science and Technology Unit for Tropical and \\ Subtropical Areas in Culiacán. \\ Carretera El Dorado Km 5.5, Culiacán 82112, Sinaloa, Mexico
}

http://doi.org/10.35410/IJAEB.2019.4449

\begin{abstract}
The increasing worldwide demand for Nile tilapia heightens the need to develop novel ingredients suitable for balanced diets. Successful partial replacement of fish oils with vegetable oils is well-documented where adequate growth has been obtained and commercial size reached within a reasonable time period. Our trials on tilapia (Oreochromis niloticus) produced no changes in feeding behavior when Jatropha curcas oil $(\mathrm{JcO})$ and fish oil (FO) were included in their diets. Survival rate with FO was lower than all JcO inclusions Replacing $25 \%$ FO for JcO gave significantly lower growth than in any of the other treatments. And JcO-75, JcO-100 present the best growth (weight, size and gain levels) similar to Jc-0 treatment. The tilapia accepted all diet inclusions and presented normal behavior. Since JcO contains higher levels of linoleic and linolenic acid than conventional aquaculture ingredients such as fishmeal or soybean meal, its use as a lipid source was found to be feasible to complement Nile tilapia (ㅁ․ niloticus) diets.
\end{abstract}

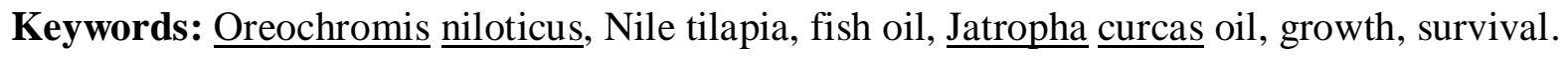

\section{INTRODUCTION}

Fish oil (FO) is the main lipid source used in formulated diets for aquaculture, it contains high amounts of n-3 polyunsaturated fatty acids (PUFAs) such as eicosapentaenoic acid (EPA) and docosahexaenoic acid (DHA) which promote survival and health, as well as make balanced diets palatable and attractive (Pike and Jackson, 2010; Teves and Razaga, 2016). The extraction and use of plant lipids as a substitute for FO in the diets of many fish species is well documented as it has been found to provide adequate fish growth and achieve commercial size within a reasonable time (Sutili et al., 2018; Turchini et al., 2009). Lim and Webster (2006) reported that Nile tilapia (․ niloticus) achieved better growth when fed diets containing vegetable sourced oils such as soybean or maize oil and they attribute this to high levels of linoleic acid (18:2 n-6). The same authors did not achieve good results with diets containing FO or beef fat despite them being rich in eicosapentaenoic acid (20:4 n-6) or oleic acid (18:1 n-9). Their study also describes how

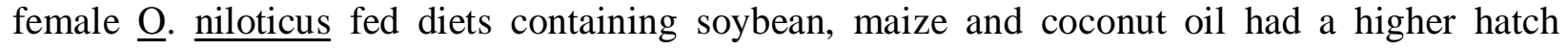


Vol. 4, No. 05; 2019

ISSN: $2456-8643$

frequency and more fry per spawn. Whilst humans consume oils such as safflower and sunflower they are also used in tilapia diets, nevertheless, several factors need to be carefully considered due to the disadvantage of having to satisfy both markets. Jatropha curcas is a drought-resistant shrub pertaining to the Euphorbiaceae family, found in wild or semi-cultivated areas in Central and South America, Africa, India, China and South-East Asia (Kumar et al., 2010). Non-toxic J. curcas kernels contain at least $55 \%$ oil and are of significant interest as a potential source of biofuel (Makkar et al., 1997; 1998a; 1998b; Achten et al., 2009). The toasted kernels of the Mexican variety when consumed by humans have no side effects (Makkar et al., 1997; 1998a; 1998b; 2009; 2011; Goel et al., 2007; Devappa et al., 2012). In order to determine their feasibility, Lucas and Southgate (2012) and Lim et al. (2008) stated that thorough assessments are necessary to determine the correct amount of $\underline{\mathbf{J}}$. curcas oil $(\mathrm{JcO})$ in tilapia feeds. FO was therefore substituted for different inclusion levels of $\mathrm{JcO}$ in the tilapia diets and considerably better growth and survival rates were achieved in our trials.

\section{MATERIALS AND METHODS}

\section{Diet formulation}

Five experimental diets each containing 35\% crude protein and 10\% lipids were formulated (MixitWin 6 Agricultural Software Consultants). Non-toxic genotype of $\underline{\mathrm{J}}$. curcas seeds were obtained from Dimas and/or San Ignacio, Sinaloa State, México. JcO was extracted from the kernels and used to replace graded levels of FO in percentages of 0, 25, 50, 75 and 100. The ingredients of the diets were homogenized and mixed in a Hobart ${ }^{\circledR}$ mixer (AND EK-4100, Korea) and the resulting paste was then pelleted in a meat grinder (Torrey® M12F8, Mexico), and passed through a $5 \mathrm{~mm}$ diameter plate disc before drying in a convection oven for $24 \mathrm{~h}$ at 60 ${ }^{\circ} \mathrm{C}$. All diets were packaged and labelled in sealed plastic bags and stored refrigerated at $4{ }^{\circ} \mathrm{C}$ throughout the experiment.

\section{Experimental set-up}

Approximately 1000 male $\underline{\text { O. }}$ niloticus were obtained from Genetilapia S.A. de C.V. (Los Pozos, El Rosario, Sinaloa, Mexico) and transported to the installations of CIAD-Mazatlán where the trial would be conducted. Plastic bags containing Nile tilapia larvae were placed in $300 \mathrm{~L}$ acclimatisation tanks (grey fiberglass) with continuous aeration until a constant temperature was reached. The experiment was conducted in a recirculation system consisting of eighteen 56L black fiberglass tanks with white interior bottoms, three filters and a reservoir $(150 \mathrm{~L})$. Each biological filter container $(70 \times 37 \times 34 \mathrm{~cm})$ was divided into three separate compartments. Wadding $(1 \mathrm{~m} \times 1.30 \mathrm{~m})$ was placed in the first compartment, the second compartment contained oyster shells and in the third, a pump (18w) was placed and used to release water into the reservoir, which was then redistributed with a $45 \mathrm{w}$ pump to all the tanks. Water was distributed from six tanks to each biological filter and water flow to each tank was maintained at $1 \pm 0.20$ $\mathrm{L} / \mathrm{min}$ and supplied with aeration. The whole system was kept at a mean temperature of $29 \pm 1$ ${ }^{\circ} \mathrm{C}$ and kept under photoperiod controlled conditions (12h light /12h dark). Before implementing the feed treatments, the tilapia were starved for $24 \mathrm{~h}$ and subsequently, all tanks were cleaned by siphoning out the faeces. Ten organisms $(1.5 \pm 0.2 \mathrm{~g}, 4.4 \pm 0.2 \mathrm{~cm})$ were stocked in each tank and fed a commercial diet over a seven-day acclimatisation period. Afterwards, each of the five 
treatments were carried out in triplicate. Feed was given three times a day until apparent satiety (8:00, 12:00 and 16:00h). Body weight and length of each individual were recorded every 15 days until the end of the experiment (45 days). To anesthetize the organisms $1.5 \mathrm{~mL}$ clove solution (1:1 clove essence: ethanol 70\%) diluted in $5 \mathrm{~L}$ of freshwater was employed and the organisms were left for 10 seconds before being weighed (AND Ek-4100 balance) and measured (digital calliper). Afterwards they were kept in clean freshwater with high aeration until completely recovered and subsequently returned to their respective tanks. Water parameters (temperature, $\mathrm{pH}$ and dissolved oxygen) were determined daily by means of an YSI-multimeter 85. Ammonium, nitrate and nitrite were measured using commercial kits (API TM) and verified twice weekly by the Chemistry and Aquatic Production Laboratory of CIAD-Mazatlán in order to provide optimal conditions for this trial study.

\section{Biochemical analyses}

Analysis for proximate composition of the diets and tilapia were carried out at the beginning and end of the experiment as follows:

- Protein: Measured with a LECO FP-528 nitrogen combustion analyser (AOAC 1990 method 990.03)

- Total Lipids: Conducted using standard petroleum-ether extraction procedures (Soxtec 2050, Foss Tecator, AOAC 1990 method 2003.06).

- Gross energy: Combustion measurements were assessed by bomb calorimetry (Parr 6725 semi micro calorimeter)

- Ash: Samples were calcined at $550{ }^{\circ} \mathrm{C}$ in a muffle furnace (ISO 5984, 1978)

- Dry matter: Determined by oven drying at $60{ }^{\circ} \mathrm{C}$ for $24 \mathrm{~h}$ Parameters to evaluate the performance of different inclusions of JcO in Nile tilapia

Diets were based on the following formulas:

- $\operatorname{Survival}(\mathrm{S}, \%)=$ final number of tilapia / initial number of tilapia (Li et $\underline{\text { al. }}$, 2011)

- Weight gain (WG, g) = final weight(g) - initial weight (g) (Li et al., 2011)

- Specific growth ratio $(\mathrm{SGR}, \% / \mathrm{d})=100 *(\ln [$ final weight] $-\ln [$ initial weight] /days) (Azaza et $\underline{\text { al., }}$ 2009; Stadtlander et al., 2013)

- Condition factor $(\mathrm{K}, \%)=100 *$ [final weight $/($ final size $) 3]$ (Morales, 2004)

- Feed conversion ratio $(\mathrm{FCR})=$ quantity of food consumed $[\mathrm{g}] /$ weight gain $[\mathrm{g}]$ Ahmad and Abdel-Tawwab, 2011; Stadtlander et al., 2013). 
Vol. 4, No. 05; 2019

ISSN: $2456-8643$

\section{STATISTICAL ANALYSIS}

Results were presented as mean \pm SD. Data were tested for normality distribution using the Kolmogorov-Smirnoff test and Bartlett's homoscedasticity test. One-way analysis ofvariance (ANOVA) was used to determine the significant differences $(\mathrm{P}<0.05)$ followed by a Duncan's multiple range test. All statistical tests were conducted using SigmaStat (version 3.0).

\section{RESULTS}

No significant difference $(\mathrm{P}>0.05)$ was found in diets for crude protein and lipid content.

On the other hand, the concentration of ash was significantly higher $(\mathrm{P}<0.05)$ with JcO administered at $25 \%$ and with gross energy at $25 \%$ and $100 \%$ (Table 1). During the experimental period, no apparent difference was observed between the feed acceptability of diets with different inclusions of $\mathrm{JcO}$. No uneaten feed was detected and behavior was normal in all tanks.

Significantly higher protein content $(\mathrm{P}<0.05)$ was found in juveniles of tilapia fed on JcO-100, 75 and -50 . The lowest lipid content was observed with tilapias fed diets containing JcO-50. Ash content was significantly lower with $\mathrm{JcO}-0$ and gross energy values were significantly lower $(\mathrm{P}<0.05)$ for $\mathrm{JcO}-50$ treatment (Table 2). Better survival occurred with all JcO inclusion (Table $3)$. Evidently, tilapia fed on JcO-25 were significantly lighter and smaller $(\mathrm{P}<0.05)$ with much lower specific growth ratio (SGR) than in all other treatments (Table 3). Best final weights were achieved with $\mathrm{JcO}-75$ and -100 .

\section{DISCUSSION}

Our findings indicate that diets of mixed $\mathrm{FO}$ and $\mathrm{JcO}$ can be considered as alternative lipid sources for tilapia. Even thou those with JcO demonstrate better results than the control (JcO-0). Tilapia fed on diets containing the percentage of $\mathrm{JcO}-75$ and -100 , gained more weight and were significantly different $(\mathrm{P}<0.05)$ than those fed on $\mathrm{JcO}-0,-25$ and -50 . The poor growth obtained with diets containing Jc0-25 can be attributed to the higher ash contained in the diets rather than the other diets, however further studies need to be done for better explanation. Treatments JcO75 and -100 , both present the highest weight gain (Table 3). JcO-25 was the smallest sized tilapia at the end (45d) of the experiment. The best feed conversion ratio (FCR) was recorded with JcO100 which was significantly better than all other treatments (Table 3). The water parameters reported in this experiment were acceptable: temperature $29{ }^{\circ} \mathrm{C} \pm 1,33 \%$ oxygen saturation, 0.1 PSU, nitrate 0.0, nitrate 1.7, $\mathrm{pH} \mathrm{7,} \mathrm{and} \mathrm{hardness} \mathrm{was} \mathrm{between} \mathrm{153-204} \mathrm{mg} \mathrm{L-1} \mathrm{(Lim} \mathrm{and}$ Webster, 2006; Suresh and Bhujel, 2012).

Common plant lipids extracted from safflower, soybean, maize and sunflower are often used in the fish industry and are commonly consumed by humans (Lim et al., 2008 and Suresh and Bhujel, 2012). In this study we found that tilapia were able to tolerate the effects of FO by replacing with $\mathrm{JcO}$ at $0,25,50,75$ and $100 \%$, thus confirming that many plant/vegetable oil sources are good for diets. According to Lim and Webster (2006), diets for Nile tilapia need no more than $12 \%$ lipids and a source of essential fatty acids (EFA). 
Vol. 4, No. 05; 2019

ISSN: $2456-8643$

Substantial evidence shows that when linoleic acid (18:2 n-6) is included in tilapia diets, the nutrition quality improves and as a result promotes a higher proportion of spawning females, more frequent spawns and larger numbers of fry per spawn. Vegetables are a good source of linoleic acid-rich oils (Lim and Webster, 2006). Puello-Cruz et al. (2018) confirms that $\underline{J}$. curcas contain significantly higher linolenic acid than fishmeal and soybean meal, therefore using $\mathrm{JcO}$ as a lipid source in tilapia diets is recommended. Since day one of the experiment, normal consumption and acceptability was observed in all treatments. Nile tilapia are known to be resistant and can survive and grow on almost any diet, their omnivorous characteristics call for a combination of animal and vegetable ingredients in order to obtain optimal growth.

\section{CONCLUSIONS}

Nevertheless, further studies are needed to assess why the growth rate worsened when $25 \%$ FO was substituted with $\mathrm{JcO}$. The results of this study conclude that when 75 and $100 \%$ levels of FO are replaced by $\mathrm{JcO}$, growth rate (length and weight) is significantly better than in the other treatments. Survival gave even better results for all JcO inclusions than FO-100\% diets.

\section{Declaration of Competing Interest}

The authors declare no conflicts of interest.

\section{Acknowledgements}

This research was supported by the CONACyT-FORDECyT project146409 entitled "Desarrollo sustentable de la cadena agroindustrial de Jatropha curcas, para el rescate de la zona serrana marginada del noroeste de México". The authors wish to thank Valerie Williams for revising the English text, and with particular thanks to Dr. Omar Calvario-Martínez and Miguel A. SánchezRodríguez (M.Sc.) of the Chemistry and Aquatic Production Laboratory, CIAD-Mazatlán who provided the water quality parameters throughout this study.

\section{REFERENCES}

Ahmad, M.H., Abdel-Tawwab, M., 2011. The use of caraway seed meal as a feed additive in fish diets: growth performance, feed utilization, and whole-body composition of Nile tilapia, Oreochromis niloticus (L.) fingerlings. Aquaculture 314,110-114. http://doi.org/10.1016/j.aquaculture.2011.01.030.

Achten, W.M.J., Maes, W.H., Aerts, R., Verchot, L., Trabucco, A., Mathijs, E., Singh, V.P., Muys, B., 2009. Jatropha: From global hype to local opportunity. J. Arid. Environ. http://doi:10.1016/j.jaridenv.2009.08.010.

AOAC, 1990. Official Methods of Analysis, 15th edition. Association of Official Analytical Chemists. Arlington, VA, USA.

Azaza, M.S., Wassim, K., Mensi, F., Abdelmouleh, A., Brini, B., Kraïem, M.M., 2009. Evaluation of faba beans (Vicia faba L. var. minuta) as a replacement for soybean meal in 
Vol. 4, No. 05; 2019

ISSN: $2456-8643$

practical diets of juvenile Nile Tilapia Oreochromis niloticus. Aquaculture 287,174-179. http://doi.org/10.1016/j.aquaculture.2008.10.007.

Devappa, R., Makkar, H.P.S., Becker, K., 2012. Localisation of antinutrients and qualitative identification of toxic components in Jatropha curcas seed. J. Sci. Food. Agr. 92, 1519-1525. http://doi.org/10.1002/jsfa.4736.

Goel, G., Makkar, H.P.S., Francis, G., Becker, K., 2007. Phorbol esters: structure, biological activity, and toxicity in animals. Int. J. Toxicol. 26,279-288. http://doi:10.1080/10915810701464641.

Kumar, V., Akinleye, A.O., Makkar, H.P.S., Angulo-Escalante, M.A., Becker, K., 2010. Growth performance and metabolic efficiency in Nile tilapia (Oreochromis niloticus L.) fed on a diet containing Jatropha platyphylla kernel meal as a protein source. J. Anim. Physiol. A. N. 96(1), 37-46. http:// doi.org/10.1111/j.1439-0396.2010.01118.x.

Li, E., Lim, C., Cai, C., Klesius, P.H., 2011. Growth response and resistance to Streptococcus iniae of Nile Tilapia, Oreochromis niloticus, fed diets containing different levels of wheat distiller's dried grains with solubles with or without lysine supplementation. Anim. Feed. Sci. Tech. 170:246-255. http://doi.org/10.1016/j.anifeedsci.2011.09.002.

Lim, C., Webster, C.D., 2006. Nutrition requirements, in: Lim C., Webster C.D (Eds). Tilapia. Biology, Culture and Nutrition. Food Products Press, New York, USA. Pp.469-501.

Lim, C., Webster, C.D., Lee, C.-S., 2008. Alternative protein sources in aquaculture diets. The Haworth Press, New York, USA. Lucas, J.S., Southgate, P.C., 2012. Aquaculture farming aquatic animals and plants. 2nd edition. Wiley-Blackwell Oxford, USA.

Makkar, H.P.S., Aderibigbe, A.O., Becker, K., 1998a. Comparative evaluation of non-toxic and toxic varieties of Jatropha curcas for chemical composition, digestibility, protein degradability and toxic factors. Food Chem 62(2), 207-215.http://doi.org/10.1016/S0308-8146 (97)00183-0.

Makkar, H.P.S., Becker, K., Sporer, F., Wink, M., 1997. Studies on nutritive potential and toxic constituents of different provenances of Jatropha curcas. J. Agric. Food Chem. 45(8), 3152-3157. http://doi: 10.1021/jf970036j.

Makkar, H.P.S., Becker, K., Schmook, B., 1998b. Edible provenances of J. curcas from Quintana Roo state of México and effect of roasting on antinutrient and toxic factors in seeds. Plant Food Hum Nutr 52(1), 31-36. http://doi: 10.1023/A: 1008054010079.

Makkar, H.P.S., Kumar, V., Oyeleye, O.O., Akinleye, A.O., Angulo-Escalante, M.A., Becker, K., 2011. Jatropha platyphylla, a new non-toxic Jatropha species: physical properties and chemical constituents including toxic and antinutritional factors of seeds. Food Chem. 125, 6371. http://doi.org/10.1016/j.foodchem.2010.08.037. 
Makkar, H., Maes, J., De Greyt, W., Becker, K., 2009. Removal and degradation of phorbol esters during pre-treatment and transesterification of Jatropha curcas oil. J. Am. Oil Chem. Soc. 86,173-181. http://doi 10.1007/s11746-008-1327-6.

Morales, G.M. 2004. Crecimiento y eficiencia alimentaria de trucha arco iris (Oncorhynchus $\underline{\text { mykiss) }}$ en jaula bajo diferentes regímenes de alimentación. Master's thesis. Universidad de Buenos Aires, Argentina.

Pike I.H., Jackson A., 2010. Fish oil: production and use now and in the future. Lipid Technology. 22(3), 59-61. http://doi 10.1002/lite.201000003.

Puello-Cruz, A.C., Ordoñez-Rosas, M.L., García-Ortega, A., Angulo-Escalante, M.A., AlmazánRueda, P., Domínguez-Jiménez, V.P., 2018. Biochemical composition and evaluation of Jatropha cucas meal as a replacement for fishmeal in diets of juvenile Nile tilapia (Oreochromis niloticus). Trop. Subtrop. Agroecosyt. 21,273-282.

Suresh, V., Bhujel, R.C., 2012. Tilapias, in: Lucas, J.S., Southgate, P.C. (eds.) Aquaculture farming aquatic animals and plants. Wiley-Blackwell Ltd., Iowa, USA, pp. 338-364.

Stadtlander, T., Khalil, W.K.B., Focken, U., Becker, K., 2013. Effects of low and medium levels of red alga Nori (Porphyra yezoensis Ueda) in the diets on growth, fed utilization and metabolism in intensively fed Nile Tilapia Oreochromis niloticus (L.). Aquacult. Nutr. 19, 64-73. http://doi.org/10.1111/j.1365-2095.2012.00940.x.

Sutili F.J., Gatlin III, D.M., Heinzmann, B.M., Baldisserotto, B., 2018. Plant essential oils as fish diets additives: benefits on fish health and stability in feed. Rev. Aquacult. 10,716-726. http://doi: 10.1111/raq.12197.

Teves, J.F.C., Ragaza, J.A., 2016. The quest for indigenous aquafeed ingredients: a review. Rev. Aquacult. 8,154-171. http://doi.org/10.1111/raq.12089.

Turchini, G.M., Torstensen, B.E., Ng, W.-K., 2009. Fish oil replacement in finfish nutrition. Rev. Aquacult. 1, 10-57. http://doi: 10.1111/j.1753-5131.2008.01001.x. 
Table 1. Composition and proximate content ( $\mathrm{g} / \mathrm{kg}$ dry matter) of the experimental diets with different percentages of Jatropha curcas oil (JcO -0, -25, -50, -75, -100 \%) as a

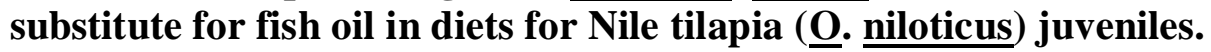

\begin{tabular}{|llllll|}
\hline Ingredients (g/kg feed) & JcO-0 & JcO-25 & JcO-50 & JcO-75 & JcO-100 \\
\hline Fishmeal & 380 & 380 & 380 & 380 & 380 \\
Soybean meal & 301.5 & 301.5 & 301.5 & 301.5 & 301.5 \\
Dextrin & 158.5 & 158.5 & 158.5 & 158.5 & 158.5 \\
Soybean protein concentrate & 50 & 50 & 50 & 50 & 50 \\
Fish oil & 60 & 45 & 30 & 15 & 0 \\
Jatropha curcas oil & 0 & 15 & 30 & 45 & 60 \\
Alginate & 20 & 20 & 20 & 20 & 20 \\
Mineral and vitamin premix & 20 & 20 & 20 & 20 & 20 \\
Calcium phosphate & 10 & 10 & 10 & 10 & 10 \\
Proximate content (g/kg dry matter) & & & & \\
Crude protein (\%) & $35.9 \pm 0.2$ & $35.7 \pm 0.1$ & $35.2 \pm 0.3$ & $35.7 \pm 0.2$ & $35.3 \pm 0.1$ \\
Crude lipid (\%) & $10.1 \pm 0.1$ & $10.8 \pm 0.1$ & $10.5 \pm 0.1$ & $10.5 \pm 0.1$ & $10.2 \pm 0.1$ \\
\hline Crude ash (\%) & $9.7 \pm 0.1 \mathrm{~b}$ & $10.8 \pm 0.3 \mathrm{a}$ & $9.7 \pm 0.1 \mathrm{~b}$ & $9.8 \pm 0.2 \mathrm{~b}$ & $9.7 \pm 0.1 \mathrm{~b}$ \\
\hline Gross energy (kJ/g) & $18.5 \pm 0.1 \mathrm{~b}$ & $19.7 \pm 0.1 \mathrm{a}$ & $18.6 \pm 0.2 \mathrm{~b}$ & $18.7 \pm 0.1 \mathrm{~b}$ & $19.1 \pm 0.1 \mathrm{a}$ \\
\hline
\end{tabular}

Values are means of all organisms from the three replicates \pm SD. Different superscripts per row differ significantly $(\mathrm{P}<0.05) . \mathrm{a}>\mathrm{b}$ 


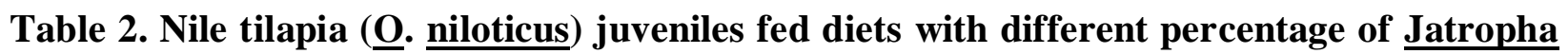
curcas oil (JcO -0, $-25,-50,-75,-100 \%)$ as a substitute for fish oil.

\begin{tabular}{|lccccc|}
\hline & JcO-0 & JcO-25 & JcO-50 & JcO-75 & JcO-100 \\
\hline Crude protein (\%) & $58.2 \pm 0.4^{\mathrm{c}}$ & $59.1 \pm 1.1^{\mathrm{b}}$ & $59.7 \pm 0.3^{\mathrm{a}}$ & $59.5 \pm 0.8^{\mathrm{a}}$ & $63.0 \pm 0.5^{\mathrm{a}}$ \\
Crude lipid (\%) & $15.5 \pm 0.4^{\mathrm{b}}$ & $15.9 \pm 0.3^{\mathrm{b}}$ & $13.8 \pm 0.2^{\mathrm{c}}$ & $17.1 \pm 0.2^{\mathrm{a}}$ & $15.5 \pm 0.7^{\mathrm{b}}$ \\
Crude ash (\%) & $14.6 \pm 0.5^{\mathrm{c}}$ & $15.4 \pm 0.1^{\mathrm{a}}$ & $15.3 \pm 0.2^{\mathrm{a}}$ & $15.0 \pm 0.1^{\mathrm{b}}$ & $15.6 \pm 0.6^{\mathrm{a}}$ \\
Gross energy (kJ/g) & $19.5 \pm 0.1^{\mathrm{ab}}$ & $19.7 \pm 0.1^{\mathrm{ab}}$ & $19.2 \pm 0.1^{\mathrm{b}}$ & $20.3 \pm 0.1^{\mathrm{a}}$ & $19.8 \pm 0.1^{\mathrm{a}}$ \\
\hline
\end{tabular}

Values are means of all organisms from the three replicates \pm SD. Different superscripts per row differ significantly $(\mathrm{P}<0.05) . \mathrm{a}>\mathrm{b}>\mathrm{c}$

Table 3. Growth performance and nutrient utilization of Nile tilapia (․․ niloticus) juveniles fed different percentages $(0,25,50,75,100 \%)$ of Jatropha curcas oil $(\mathrm{JcO})$ as a substitute for fish oil.

\begin{tabular}{|lllclc|}
\hline & JcO-0 & JcO-25 & JcO-50 & JcO-75 & JcO-100 \\
\hline Initial length (cm) & $4.4 \pm 0.2$ & $4.4 \pm 0.2$ & $4.4 \pm 0.2$ & $4.4 \pm 0.2$ & $4.4 \pm 0.2$ \\
Final length (cm) & $9.5 \pm 1.1^{\mathrm{a}}$ & $8.9 \pm 0.9^{\mathrm{b}}$ & $9.5 \pm 1.3^{\mathrm{a}}$ & $9.5 \pm 0.7^{\mathrm{a}}$ & $9.5 \pm 0.8^{\mathrm{a}}$ \\
Initial weight (g) & $1.5 \pm 0.2$ & $1.5 \pm 0.2$ & $1.5 \pm 0.2$ & $1.5 \pm 0.2$ & $1.5 \pm 0.2$ \\
Final weight (g) & $15.7 \pm 5.6^{\mathrm{b}}$ & $13.1 \pm 3.9^{\mathrm{c}}$ & $15.1 \pm 5.0^{\mathrm{b}}$ & $16.1 \pm 2.1^{\mathrm{a}}$ & $16.2 \pm 3.1^{\mathrm{a}}$ \\
Survival (\%) & $90.0 \pm 4.7^{\mathrm{b}}$ & $97.0 \pm 28.3^{\mathrm{a}}$ & $97.0 \pm 4.7^{\mathrm{a}}$ & $97.0 \pm 17.0^{\mathrm{a}}$ & $97.0 \pm 12.5^{\mathrm{a}}$ \\
\hline Humidity (\%) & $75.1 \pm 0.1$ & $75.6 \pm 0.1$ & $76.0 \pm 0.1$ & $75.5 \pm 0.1$ & $76.0 \pm 0.1$ \\
\hline Weight gain (g) & $14.2 \pm 0.5 \mathrm{ab}$ & $11.6 \pm 0.7 \mathrm{c}$ & $13.6 \pm 0.2 \mathrm{~b}$ & $14.6 \pm 0.5 \mathrm{a}$ & $14.7 \pm 0.3 \mathrm{a}$ \\
\hline SGR (\%) & $5.2 \pm 0.3 \mathrm{a}$ & $4.8 \pm 0.3 \mathrm{c}$ & $5.1 \pm 0.6 \mathrm{~b}$ & $5.3 \pm 0.4 \mathrm{a}$ & $5.3 \pm 0.1 \mathrm{a}$ \\
\hline K & $1.8 \pm 0.1$ & $1.9 \pm 0.1$ & $1.8 \pm 0.1$ & $1.9 \pm 0.1$ & $1.9 \pm 0.1$ \\
\hline FCR & $1.9 \pm 0.1 \mathrm{~b}$ & $2.3 \pm 0.1 \mathrm{a}$ & $1.7 \pm 0.1 \mathrm{bc}$ & $1.8 \pm 0.1 \mathrm{~b}$ & $1.5 \pm 0.2 \mathrm{c}$ \\
\hline
\end{tabular}

SGR: specific growth rate; K: condition factor; FCR: feed conversion ratio. Values are means of all organisms and three replicates $\pm \mathrm{SD}$. Different superscripts per row differ significantly $(\mathrm{P}<0.05)$. $\mathrm{a}>\mathrm{b}>\mathrm{c}$ 